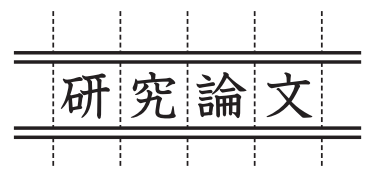

\title{
熱流体解析によるチップオンウエハにおける熱摇らぎ挙動の定量化 \\ Quantification of Thermal Fluctuation Behavior in Chip on Wafer Process by Thermo-fluid Analysis
}

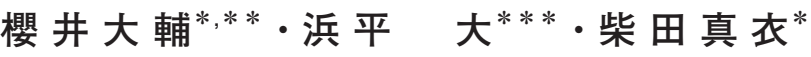 \\ 那須 博*・福本 信 次**・藤本公三** \\ Daisuke SAKURAI, Masaru HAMAHIRA, Mai SHIBATA, \\ Hiroshi NASU, Shinji FUKUMOTO and Kozo FUJIMOTO
}

(Received September 1, 2018)

\begin{abstract}
Recently, demand for the fan-out wafer level package is increasing because the market of IoT (Internet of Things) devices is expanding. Especially, higher accuracy and higher productivity are required for the chip-on-wafer bonding process. However, the process has the issue about the recognition accuracy caused by heat haze on the heated wafer. Therefore, the authors examined the quantification of thermal fluctuation behavior which fluctuates due to the temperature of wafer and jet flow by the thermo-fluid analysis. The bonder units such as bonding head, wafer and camera were modeled to clarify the thermal fluctuation behavior in the die bonder. The influence of the heated wafer and jet flow on the velocity and temperature of air was evaluated by the thermo-fluid analysis. Furthermore, the validity of the analysis was verified by the particle image velocimetry (PIV).
\end{abstract}

Key Words: Die Attach, High Accuracy, Chip on Wafer, Heat Haze, Heat Flow, Fan-out Wafer Level Package

\section{1. 緒 言}

近年、工場、自動車、インフラなどのあらゆるモノがネッ トに繋がる IoT (Internet of Things) 市場が急拡大している。 このような中、センサやカメラ等から得られた大量の情報 を高速通信・高速処理するアプリケーションプロセッサや 通信モジュールなどの先端半導体パッケージの市場は急拡 大し、2020 年には現在の 5 倍になると予測されている。従 来のように樹脂多層基板にダイを 1 個ずつ実装する半導体 パッケージでは、伝送特性・薄型化・生産性・コストの観 点で限界に近付きつつある。

このような中、TSV (Through Silicon Via)の形成されたシ リコンインターポーザやガラスインターポーザーを用いダ イを垂直方向に積層する 2.5D、3D 実装の開発が進んでき た ${ }^{1)}$ 。この生産プロセスは、個片化された基板に 1 個ずつ 実装するよりもコストが下がる、ウエハサイズの異なる素 子同士の積層ができるように、大口径のウエハ上にダイを 実装するチップオンウエハ方式が着目されている。

さらに、数十年に一度の半導体パッケージ革新技術とし て FOWLP (Fan-Out Wafer Level Package) や PLP (Panel Level
Package）が着目されており、様々なパッケージ構造が提案 されている ${ }^{2) \sim 7)}$ 。FOWLPやPLPは、半導体ウエハを個片 化したダイを樹脂に内蔵することにより外形寸法を拡張 し、ダイの電極端子から電極ピッチを拡大するように樹 脂の最表面の外部接続端子に向かって再配線層 (RDL ; redistribution layer) と呼ばれる 3 次元配線で引き出す構造の半 導体パッケージである。個片化されたダイを、WLPでは大 口径ウエハにPLP では大型基板に、一定間隔で再配列した 後、再配線を行い、ウエハや基板は剥離・除去する。その ため、樹脂多層基板やインターポーザが不要となり、上述 の問題点を解決できる。FOWLP の市場は、2015 年の 25 億 円から年率 $32 \%$ で成長し、2020 年には 2,400 億円への拡大 が予測されている8)。

以上のように、先端半導体パッケージの生産プロセスは、 樹脂多層基板を用いた 1 by 1 プロセスから、大口径ウエハ を用いた一貫プロセスへと進化しつつある。

チップオンウエハの実装方式は、ウエハの配線パターン に対向するようにフリップチップ実装する方式と、ウエハ 上にダイをフェースアップで実装した後、再配線を行うダ

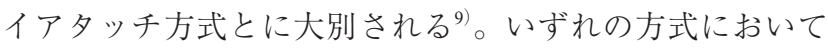

*パナソニック株式会社 生産技術本部（一 517-8502 大阪府門真市松葉町 2-7）

Manufacturing Technology and Engineering Division, Panasonic Corporation (2-7 Matsuba-cho, Kadoma City, Osaka 571-8502, Japan)

**大阪大学大学院工学研究科（干 565-0871 大阪府吹田市山田丘 2-1）

Graduate School of Engineering, Osaka University (2-1 Yamadaoka, Suita City, Osaka 565-0871, Japan)

***パナソニックスマートファクトリーソリューションズ株式会社（⿳亠口了丁 812-8531 福岡県福岡市博多区美野島 4-1-62）

Panasonic Smart Factory Solutions Co.,Ltd.(4-1-62 Minoshima, Hakata-ku, Fukuoka 812-8531, Japan) 
も、ダイの電極端子と再配線との位置合わせが重要であり、 実装の高精度化が求められる。また、いずれも素子を 1 個 ずつ実装するため、実装工程が生産リードタイムのボトル ネック工程となっており、実装の高生産性が求められる。

そこで、高精度と高生産性を両立するために、半導体実 装機において、実装へッドの防振·軽量化機構、高剛性機構、 重心駆動化制御、画像認識手法アルゴリズムに関する研究 開発が行われてきた ${ }^{10), 11}$ 。

フリップチップ方式においては、著者らはチップオン ウエハに対応したマイクロはんだ接合方式による高生産 フリップチップ実装工法を開発してきた ${ }^{12)}$ 。ウエハ上の狭 ピッチ電極パッドに高速ではんだ接合を行うには、ウエハ の加熱は必須になる。

一方、ダイアタッチ方式については、従来用途では後工 程のワイヤボンディング工程における実装精度の許容範囲 が広いため、主に生産性に特化した開発が進んできた。し かし、従来の実装機構では、ダイ裏面形状で位置合わせを 行うため、ダイの外形ばらつきによって認識誤差が大きく なり、高精度化に限界がある。そのため、高精度ダイアタッ チ機構開発が必要である。また、一貫プロセスで後工程の 位置ずれを抑えるため、熱硬化・熱可塑接着材やはんだを 用いた加熱実装プロセスにより接着・接合強度を確保する 必要がある。

これらの実装工程において、大口径ウエハを加熱すると、 認識カメラの光路中の空気が熱で摇らぐことにより、認識 誤差が大きくなる問題があった。実装プロセスにおける熱 摇らぎは、陽炎(かげろう) と呼ばれ、技術者の経験や勘に

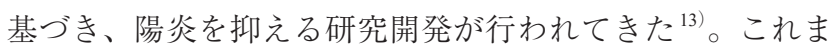
での研究では、熱摇らぎは定性的評価にとどまっており、 認識精度との因果関係も不明確であった。

そこで、本研究では、チップオンウエハにおける加熱実 装プロセスの高精度実装を狙いとし、認識精度を悪化させ る認識カメラ光路中の陽炎を熱流体解析により定量化する ことを目的とした。特に、ダイアタッチプロセスを想定し、 実装へッドに吸着したダイの認識マークが直接見える透過 式ヘッドを搭載した認識精度検証装置を作製し、検証装置 内の熱摇らぎの熱流体解析による定量化を検討した。

\section{2. 高精度ダイアタッチ機構}

2.1 チップオンウエハプロセス

チップオンウエハの一貫プロセスの一例として、FOWLP の生産プロセスを Fig. 1 に示す。まず、Fig. 1 (a) に示すよ うに、ウエハ上に一定間隔でダイアタッチを行う。ダイ裏 面にDAF (die attach film)を貼り付けるないしは、ウエハに 接合材料を塗布した後、接合材料の接合温度にて加熱実装 を行う、次に、Fig. 1 (b) のように、ダイを樹脂封止した後、 複数のダイの電極端子に合うように位置合わせを行い、再 配線層を形成する。その後、ウエハを除去し個片化するこ とにより半導体パッケージは形成される。
以上のプロセスを想定し、チップオンウエハにおける目 標実装精度は、電極端子の狭ピッチ化、異種ダイ実装への 対応や実装後のモールドでの位置ずれ等を考慮し、 $\pm 3 \mu \mathrm{m}$

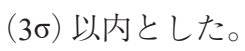

\section{2 高精度ダイアタッチ機構の特徵}

Fig. 2 は、従来の高速ダイボンダの構成である。構成を 分析し、実装精度 $\pm 3 \mu \mathrm{m}$ 達成に向けた課題を 3 点抽出した。 1）従来へッドでは、吸着したダイ表面が見えないため、 ダイ董面からアップルッキングカメラで撮像し外形 で位置合わせする方法や、吸着前にダイ表面を認識す る方法が採られる。しかし、前者ではダイシング時に DAF にバリが生じ外形寸法がばらつき、後者では吸着 動作時に吸着位置がばらつく。従って、吸着したダイ 表面が見えるへッドの開発が必要である。

2）認識カメラをダイ用と基板用に分離すると、2 台のカメ ラ間で認識誤差が生じる。そこで、同一カメラでダイ と基板を認識する機構開発が必要である。

3）認識時に振動の影響を減らすには、カメラと被測定物 板との距離を近づけた方が良い。しかし、加熱した被 測定物に近づけ撮像すると、輻射熱により空気がゆら ぐ「陽炎」により認識精度が $\pm 10 〜 \pm 15 \mu \mathrm{m}$ ばらつく。 陽炎を効率的に取り除く機構開発が必要である。

そこで、以下の開発コンセプトを掲げ、検証装置を設計・ 試作し、評価を行った。

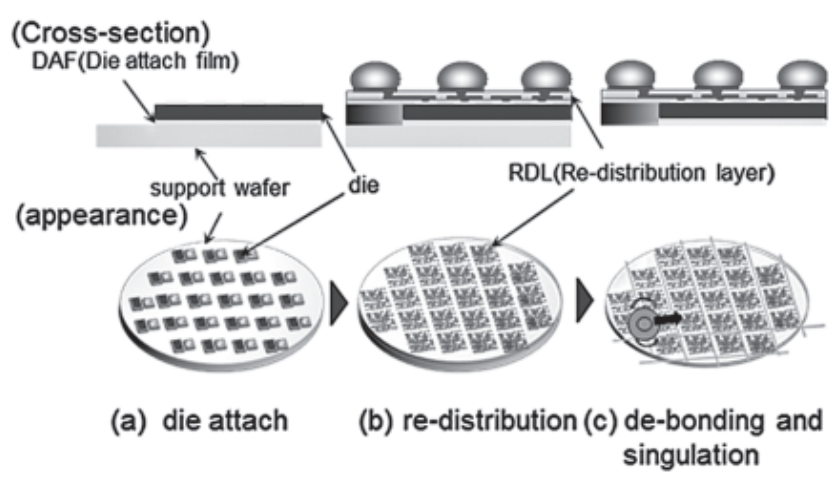

Fig. 1 Fabrication process of the Fan-Out Wafer Level Package.

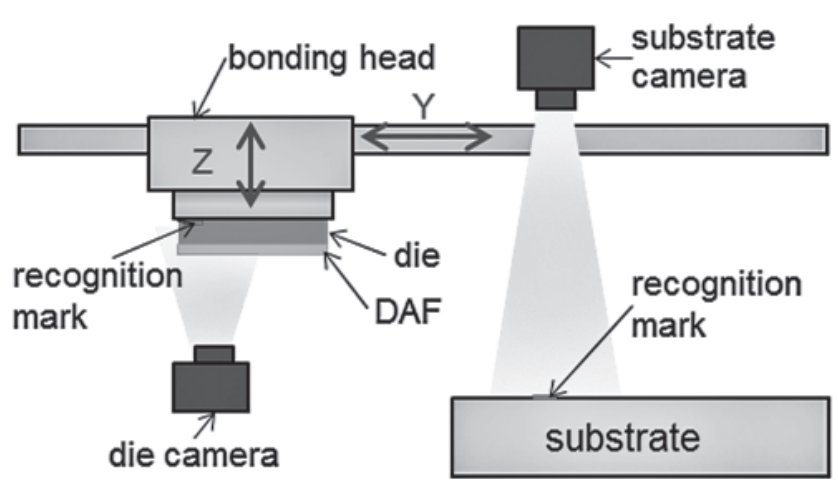

Fig. 2 Structure of the conventional die bonder. 
1）吸着したダイの認識マークで直接位置合わせが可能

2）ダイと基板の認識マークを同一カメラで同時に撮像

3）陽炎を除去しダイと基板を実装直前に近距離で撮像

\section{3 検証モデル機構}

Fig. 3 は、検証に用いた $300 \mathrm{~mm}$ ウエハ対応高精度実装 機 (パナソニック製) の概略図である。装置構成について説 明する。まず、ピックアップしたダイをへッドに受け渡し 吸着する。次にダイと加熱ステージ上の基板を認識マーク で位置合わせした後、ヘッドを下降し実装する。

ここで、ヘッドで吸着したダイの認識マークを認識する 方法としては、赤外線カメラでダイ裏面から認識マークを 透過する方法や、ダイより小さなツールで吸着し斜め上方 からダイを撮像する方法が知られている。しかし、前者で は DAF 内部にある数ミクロンから数十ミクロン径の粉末や 気泡が認識を阻害する。後者では、実装時にダイ端部に熱・ 荷重がかからず、後工程や使用環境において剥離不良の懸 念がある。

そこで、ヘッド内部を透過構造とし、ヘッド側面に設置 したサイドビューカメラで認識マークを認識する方式を採 用した。本方式では DAF 付きのダイ認識とダイ全面加圧を 容易に両立できる。さらに、光学設計を工夫し、高さの異 なる基板とダイの認識マークを実装前に同時認識できるよ うにした。ダイと基板の同一視野での撮像により、認識精 度を向上させた。また、ステージからの輻射熱を防ぐため サイドビューカメラ周辺にはカバーを設けた。さらに、カ メラカバーと透過ヘッドの間の陽炎を除去するように、紙 面に対し垂直方向に噴射するように陽炎ブローノズルを設 置した。

\section{3. 実験方法}

\section{1 熱流体解析方法}

\section{1 .1 支配方程式}

陽炎は、空気が不規則に加熱されることにより局所的に 空気の密度差が生じ、空気を通った光が様々な方向に屈折 することで起きる。

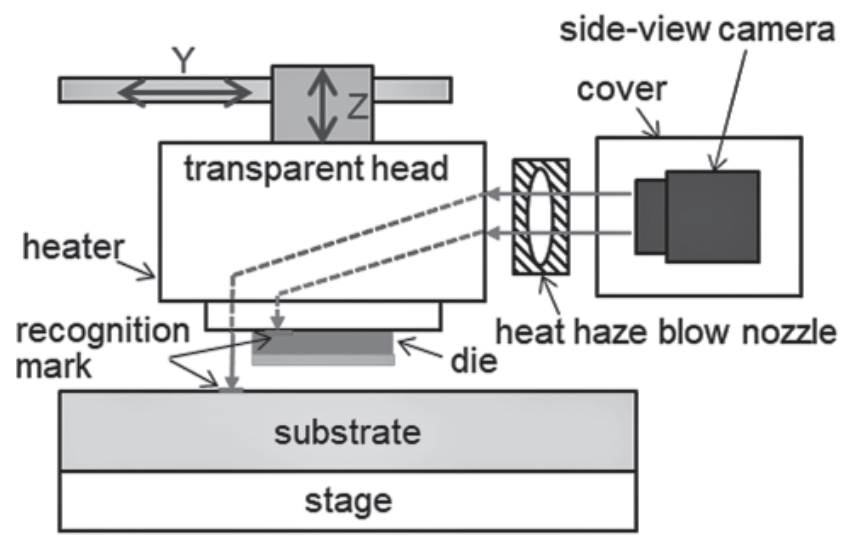

Fig. 3 Structure of the developed die bonder.
空気の流れ場では、大小の渦の生成と消滅がランダムに 生じる乱流の挙動を示す。乱流の渦は時間的にも空間的 にも複雑で不規則な動きを示す。乱流の解析手法として は、主に、直接数值シミュレーション法 (Direct Numerical Simulation)、格子平均モデル (Large Eddy Simulation)、レイ ノルズ平均モデル (Reynolds-Averaged Navier-Stokes; RANS) が知られている。平均的な流れや温度の傾向を捉えること ができ、この 3 手法の中で最も計算負荷も低いことから、 乱流を空間的・時間的に平均したレイノルズ平均モデルを 用いた。

また、実装ステージやヘッドの熱によって温められた空 気の熱摇らぎを、非圧縮性流体の自然対流と考え、密度に 関するブシネスク近似 ${ }^{5,(6)}$ を適用した。対流を表す方程式 を以下に示す。

$$
\begin{gathered}
\rho_{0} \frac{\partial \overline{u_{i}}}{\partial t}+\rho_{0} u_{i} \frac{\partial \overline{u_{i}}}{\partial x_{j}} \\
=-\frac{\partial \bar{p}}{\partial x_{i}^{2}}+v \frac{\partial^{2} \overline{u_{i}}}{\partial x_{j}^{2}}-\frac{\partial \overline{u_{i}^{\prime} u_{j}^{\prime}}}{\partial x_{j}}+\left(\rho-\rho_{0}\right) g \\
\left(\rho-\rho_{0}\right) g=-\rho_{0} \beta\left(T-T_{0}\right)
\end{gathered}
$$

ここで、 $t$ は時間、 $x_{i} 、 x_{j}$ は直交座標系の座標成分、 $u_{i} 、 u$ は $x_{i} 、 x_{j}$ 方向の流速成分であり、 $p$ は圧力成分、 $g$ は重力加 速度成分である。また、 $\rho$ は流体の密度、 $\rho_{0}$ は基準密度、 $\beta$ は熱膨張係数であり、 $T$ は流体の温度、 $T_{0}$ は基準温度である。

式 (1)、（2）が示すように、流体の温度差により密度変化 が発生し、密度差が重力に比例した浮力として流体に影響 を及ぼすと考えて解析を行った。

3.1 .2 解析モデル

解析モデルの平面図を Fig. 4 に示す。実験装置と同様に、 透過ヘッド、サイドビューカメラユニット、ステージをモ デル化し、空気の流れと温度への影響を可視化した。直径 $300 \mathrm{~mm}$ のウエハの中央部に透過ヘッドを配置し、透過ヘッ ドの側面から撮像できるようにサイドビューカメラユニッ トを配置した。さらに、陽炎ブローノズルを、 $\mathrm{x}$ 軸では透

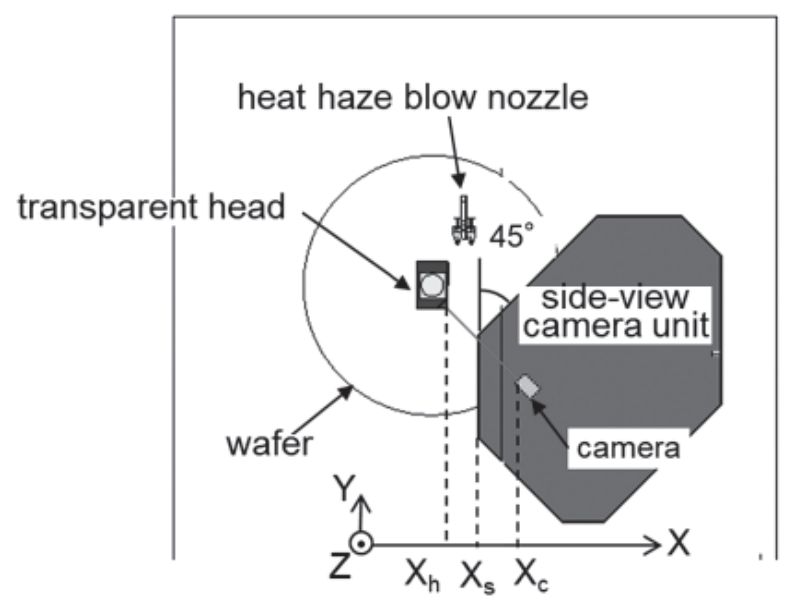

Fig. 4 The thermo-fluid analysis model. 
Table 1 Conditions of the thermo-fluid analysis model.

\begin{tabular}{cccc}
\hline Material & $\begin{array}{c}\text { Density } \\
\left(\mathrm{kg} / \mathrm{m}^{3}\right)\end{array}$ & $\begin{array}{c}\text { Specific } \\
\text { heat } \\
(\mathrm{J} / \mathrm{kg} \cdot \mathrm{K})\end{array}$ & $\begin{array}{c}\text { Thermal } \\
\text { conductivity } \\
(\mathrm{W} / \mathrm{m} \cdot \mathrm{K})\end{array}$ \\
\hline $\begin{array}{c}\text { Head } \\
\text { Solid air } \\
\left(100^{\circ} \mathrm{C}\right)\end{array}$ & 7780 & 460 & 24.3 \\
\hline
\end{tabular}

過ヘッドとサイドビューカメラの間に、y 方向に噴流が噴 出するように配置した。サイドビューカメラユニット内部 にはカメラを搭載し、透過ヘッド側面、サイドビューカメ ラ、カメラ表面の $\mathrm{x}$ 座標を $\mathrm{X}_{\mathrm{h}} 、 \mathrm{X}_{\mathrm{s}} 、 \mathrm{X}_{\mathrm{c}}$ とした。なお、解析 領域は $600 \mathrm{~mm} \times 1600 \mathrm{~mm} \times 400 \mathrm{~mm}$ とした。また、透過へッ ド内部は、擬似的に流れのない固体空気としてモデル化し た。解析に用いた構成材料の物性值を Table 1 に示す。また、 解析には汎用熱流体解析ソフトSTAR-CCM+v10.04.009 (富 士通製)を用いた。

\section{1 .3 解析条件}

一般的にダイアタッチは、接合温度 $100 \sim 150^{\circ} \mathrm{C}$ で行わ れることが多い。ウエハ温度は、加熱による反りの増大や 配線の酸化等が懸念されるため、 $150^{\circ} \mathrm{C}$ 以上は困難と考え る。ウエハが低温でも接合部を加熱できるように、ヘッド

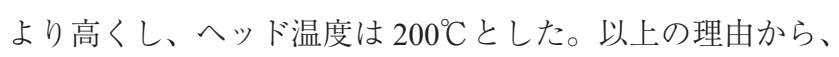

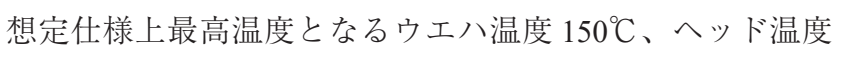
$200^{\circ} \mathrm{C} に お い て 、$ 定常解析を行った。まず、自然対流によ る熱摇らざの影響を評価するために、加熱ウエハ及びヘッ ド近傍の流速分布、温度分布を求めた。さらに、噴流によ る熱摇らぎの影響を評価するため、陽炎ブローから噴流を 噴出した場合の流速分布及び温度分布を求めた。なお、陽

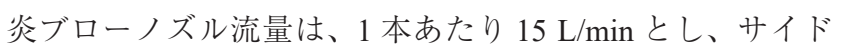
ビューカメラのカバー形状を、Fig. 4 に示すようにy方向 に対し $45^{\circ}$ 切り欠き部を備えた形状とした。

\section{2 粒子画像測定法による流速分布の測定方法}

流速の測定方法としては、熱線流速計やレーザドップ ラー流速計などが知られているが、いずれも 1 点あるいは 数点の定点計測であり、ある瞬間の流れ構造や空間相関を 知ることができない。本研究では、流れ場における多点の 瞬時速度を得ることができる流体計測手法として注目さ れている、粒子画像流速測定法 (Particle Image Velocimetry; PIV）を用いた。本手法は、流体に追従する微細トレーサ粒 子にレーザシートを照射し可視化し、カメラで撮影した流 れ画像を解析しフレーム間の微小時間における粒子の変位 ベクトルを画像処理によって求め、流体の局所速度べクト ルを計算する手法である。

$\mathrm{PIV}$ の光源には波長 $532 \mathrm{~nm}$ の $\mathrm{YVO}_{4}$ (イットリウム・バ ナデイト) レーザを、トレーサ粒子には水溶性グリコール を用いた。PIVの測定方法を Fig. 5 に示す。 z 方向の流速 測定は、Fig. 5 (a) に示すようにウエハに対し垂直方向で 2 次元断面をレーザで切断し、レーザ面に対向するようにカ

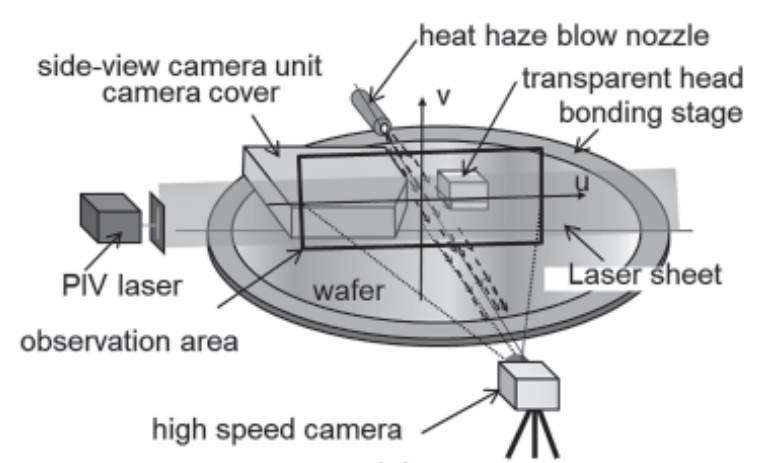

(a)

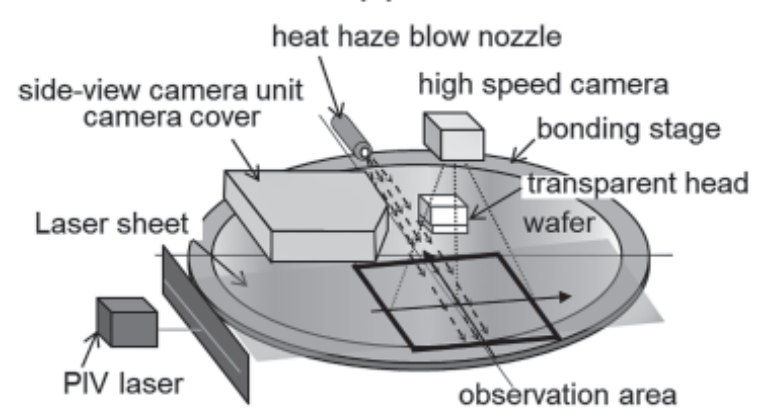

(b)

Fig. 5 The measurement method of the flow velocity in the die bonder by the particle image velocimetry; (a) cross-sectional view, (b) top view.

メラを設置·撮像し、 $\mathrm{u}$ 成分、 $\mathrm{v}$ 成分の 2 成分計測を行った。 また、一方平面方向の流速測定は、Fig. 5 (b) に示すように ウエハから平行かつ一定距離離れた平面をウエハの上方か らカメラで撮像し、2 成分計測を行った。

熱摇らぎを考慮し、画像を $2.5 \mathrm{~ms}$ 間隔で撮像し、32 フレー ムの平均值を流速とした。

\section{3 認識精度の測定方法}

透過ヘッドに吸着したダイの認識マークの画像をサイド ビューカメラで取り达み、画像処理装置によりパターン認 識し、認識マークの $\mathrm{x} 、 \mathrm{y}$ 座標を求めた。画像は一定時間間 隔で 100 回撮像し、100 回分の認識マーク位置の標準偏差 $3 \sigma$ を求め、認識精度とした。

\section{4. 結果および考察}

4.1 自然対流による熱摇らぎの定量化

4.1.1 熱流体解析による流速・温度の定量化

$150^{\circ} \mathrm{C}$ に加熱したウエハ及び $200^{\circ} \mathrm{C}$ に加熱したヘッド近傍 の空気流速分布の解析結果を Fig. 6 (a) に示す。平面方向 にヘッドから離れた位置の加熱したウエハ近傍の空気は、 ウエハから上方に向かって $0.02 \sim 0.15 \mathrm{~m} / \mathrm{s}$ と緩やかな速度 で変動しながら上昇する傾向が見られた。一方、200ㄷ に加 熱されたへッド近傍の空気は、ヘッドの側面形状に沿うよ うに上昇気流が生じ、ウエハからの上昇気流と混ざり合う ことにより、ヘッドが無い部分よりも速い速度で上昇する 傾向が見られた。 


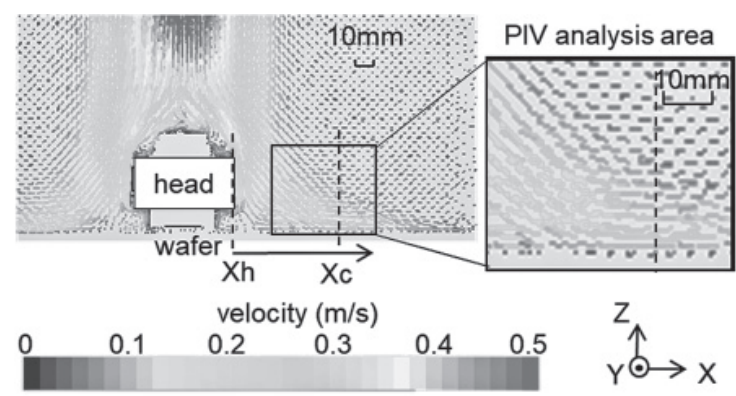

(a)

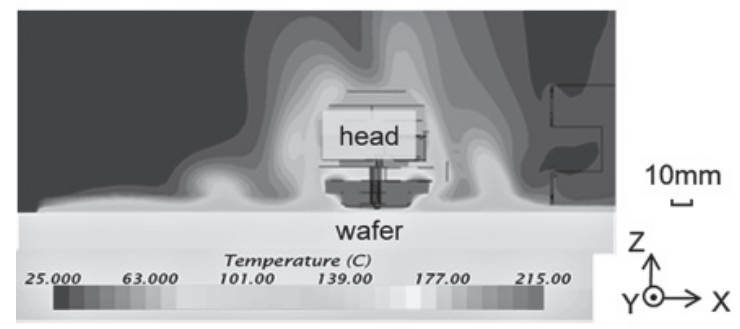

(b)

Fig. 6 Thermo-fluid analysis result of heat haze on the heated wafer with the bonding head at the temperature of $200^{\circ} \mathrm{C}$; (a) flow velocity, (b) temperature.

一方、自然対流による温度分布の流体解析結果を Fig. 6 (b)に示す。 $150^{\circ} \mathrm{C}$ に加熱されたウ工八直上の空気は、ウ工 八に近いほど高温になり、平面方向の位置に依存すること なく不均一な温度分布を示した。その理由を以下のように 考えた。ウエハによって温められた気体は、隣接する気体 粒子の温度差によって浮力に差が生じるため、上昇気流の 流速がばらつき不均一な空気の流れが発生する。その結果、 さらに温度差が拡がり、その温度差によって空気の流れが さらに不均一になったと考える。一方、ヘッド近傍の温度 は、ヘッドがウエハに対し $50^{\circ} \mathrm{C}$ 高いにも関わらず、ヘッ ド側面の極めて近い位置以外は大きな温度上昇が見られな かった。

そこで、ヘッド側面の空気の温度上昇の原因を究明する ために、熱流体解析によりウエハ・ヘッド加熱の影響を評 価した。Fig. 7 (a) はヘッドのみを $200^{\circ} \mathrm{C} に$ 加熱した場合、 Fig. 7 (b) は常温のヘッドを $150^{\circ} \mathrm{C} に$ 加熱したウエハ上に配 置した場合の温度分布の解析結果である。Fig. 7 (a) に示す ように、加熱されたヘッド表面を覆う近傍の空気は $80^{\circ} \mathrm{C}$ 程 度に温められたが、全体の温度分布には影響を与えなかっ た。一方、Fig. 7 (b) に示すように、常温のヘッドを加熱 されたウエハ上に配置した場合、ヘッド近傍から広範囲に 渡って空気の温度上昇をもたらした。ウエハの輻射熱によ り温められた気流が、ヘッドに沿って上昇することにより、 ヘッド近傍の空気に負圧が生じ流速が増幅され、温度上昇 が生じたと考える。以上より、ヘッド近傍では、ヘッド温 度よりも、ヘッドの存在自体が、空気の温度上昇に著しく 影響を及ぼすことが分かった。ヘッド側面の空気は熱摇ら ぎが生じやすいため、側面からカメラで撮像し認識処理を

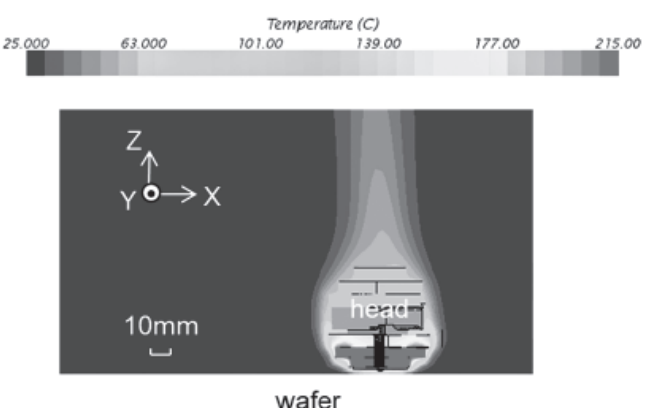

(a)

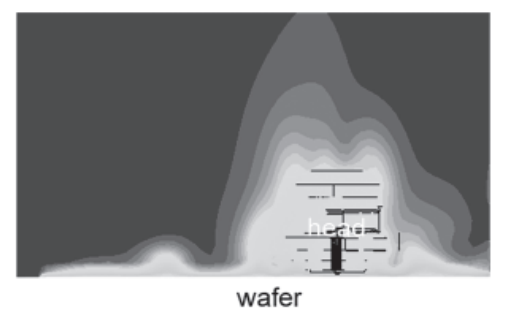

(b)

Fig. 7 Thermo-fluid analysis result of flow temperature; (a) head $200^{\circ} \mathrm{C}$, wafer: $25^{\circ} \mathrm{C}$, (b) head: $25^{\circ} \mathrm{C}$, wafer: $150^{\circ} \mathrm{C}$.

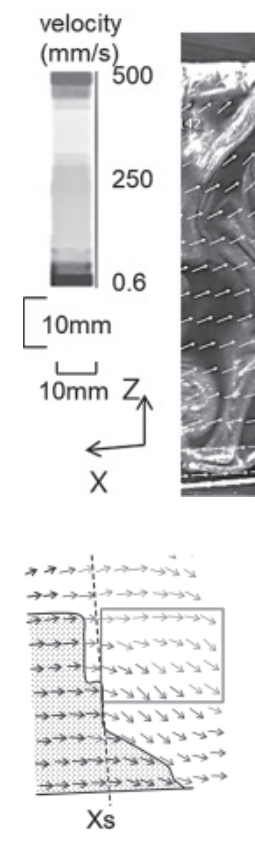

(b)

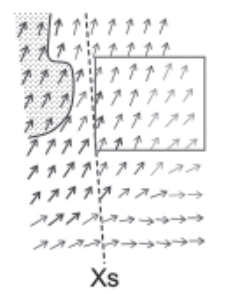

(c)

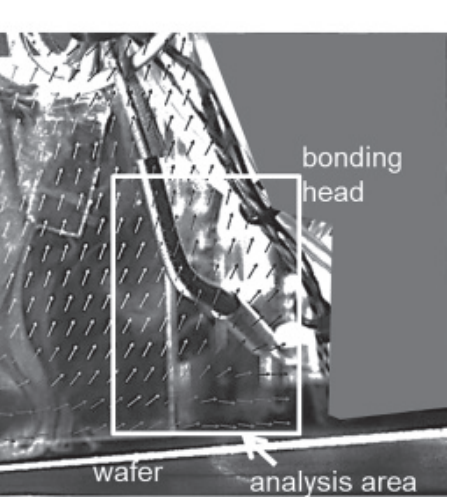

(a)

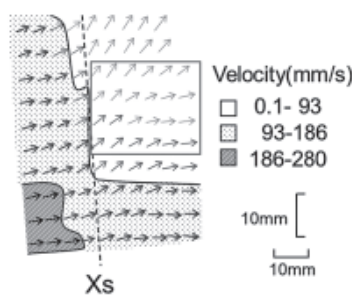

(d)
Fig. 8 The measurement result of the flow velocity distribution by the PIV method (Temperature condition; (a) head: $200^{\circ} \mathrm{C}$, wafer: $30^{\circ} \mathrm{C}$, (b) head: $30^{\circ} \mathrm{C}$, wafer: $30^{\circ} \mathrm{C}$, (c) head: $30^{\circ} \mathrm{C}$, wafer: $150^{\circ} \mathrm{C}$, (d) head: $200^{\circ} \mathrm{C}$, wafer: $150^{\circ} \mathrm{C}$ ).

行うと認識精度が悪化すると考える。

\subsubsection{PIV 法による流速分布の測定}

熱流体解析の妥当性を検証するため、PIV 法により流速 分布を測定した。Fig. 8 (a) は、断面方向の PIV 測定結果で ある。Fig. 8 (b)、（c)、（d）は、熱流体解析と同様にヘッド 温度、ウエハ温度を変えた場合の、Fig. 8 (a) 中の分析領域 
における流速分布である。Fig. 8 (b) の通り、ヘッド及びウ エハが $30^{\circ} \mathrm{C}$ の場合、気流は不規則な方向に $0.2 \mathrm{~m} / \mathrm{s}$ 以下の

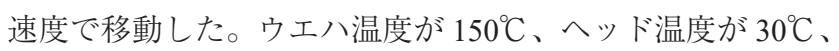
$200^{\circ} \mathrm{C}$ の場合の流速分布を Fig. 8 (c)、（d）にそれぞれ示す。 いずれの条件においても、気流が約 $0.1 \mathrm{~m} /$ の速度で摇らぎ ながら、ヘッドに沿って上昇する傾向が見られた。Fig. 6 (a)の PIV 解析領域と同様の傾向を確認した。また、熱流 体解析と同様にヘッド温度は気流分布に大きな影響を与え なかった。

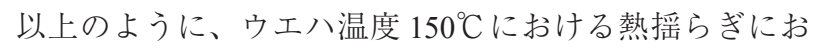
いて、熱流体解析による流速分布結果が PIV 法による測定 結果と同様の傾向を示すことを確認した。

\section{2 噴流が熱摇らぎに与える影響}

\subsection{1 熱流体解析結果}

噴流が熱摇らぎに与える影響について、熱流体解析を用 いて検討した。熱流体解析結果の流速分布の平面図を Fig. 9 に示す。Fig. 9 (a) に示すように陽炎ブローが無い場合、 前項で述べたようにヘッドを取り囲む気流は $0.1 \mathrm{~m} / \mathrm{s}$ 程度の 緩やかな速度で不規則な方向に動いた。一方、Fig. 9 (b)に 示すように陽炎ブローがある場合、ノズルから一定幅で 5 $\mathrm{m} / \mathrm{s}$ の高速の噴流が $\mathrm{y}$ 方向に向かって噴出した。噴流に引 き込まれるように周囲の気流にも流れが生じた。

一方、温度分布の解析結果の平面図を Fig. 10 に示す。

Fig. 10 (a) に示すように陽炎ブローが無い場合、実装ヘッ ドとカメラ間を結ぶ光路中の空気は、高温と低温の空気が

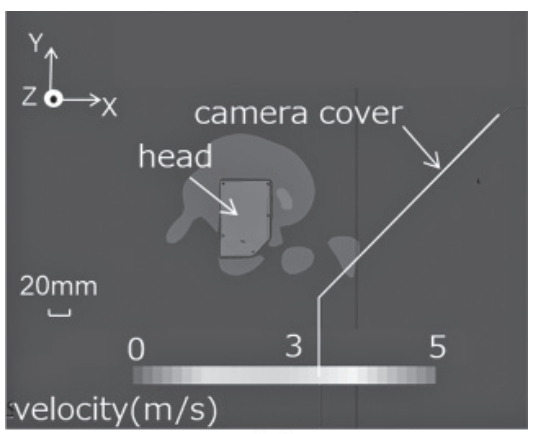

(a)

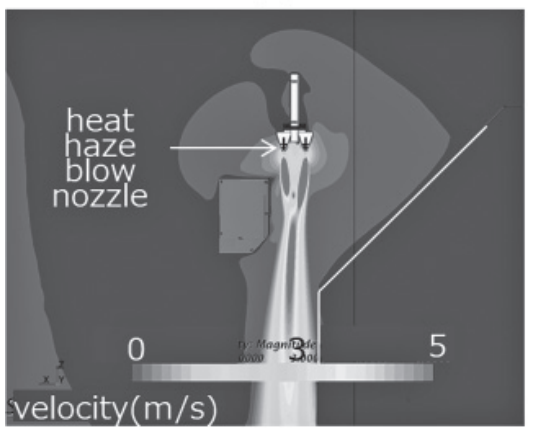

(b)

Fig. 9 Thermo-fluid analysis results of the flow velocity distribution in the horizontal direction (heat haze blow flow; (a) $0 \mathrm{~L} / \mathrm{min}$ (b) 15 $\mathrm{L} / \mathrm{min}$ ).
交互に配置される不均一な温度分布を示した。一方、Fig. 10 (b) に示すように陽炎ブローがある場合は、実装へッド とカメラ間を結ぶ光路中の空気の温度ばらつきは著しく低 減した。噴流により、陽炎の原因となるへッド近傍の温め られた空気が排出されたと考える。

垂直方向の温度分布の解析結果を Fig. 11 に示す。Fig. 11 (b) のように、陽炎ブローがある場合は、カメラとへッ ド間だけでなく、ヘッド近傍を覆っていた暖気を取り除く

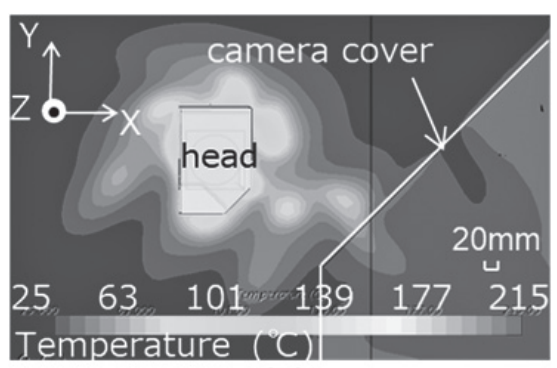

(a)

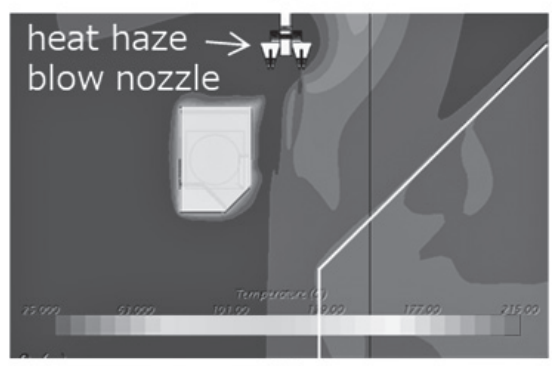

(b)

Fig. 10 Thermo-fluid analysis results of the flow temperature distribution in the horizontal direction (heat haze blow flow; (a) $0 \mathrm{~L} / \mathrm{min}(\mathrm{b}) 15 \mathrm{~L} / \mathrm{min})$.

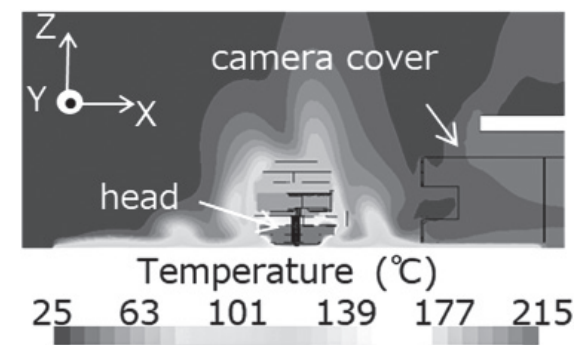

(a)

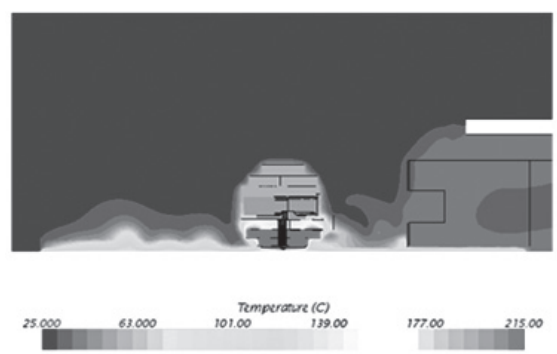

(b)

Fig. 11 Thermo-fluid analysis results of the flow temperature distribution in the vertical direction (heat haze blow flow; (a) $0 \mathrm{~L} / \mathrm{min}$ (b) $15 \mathrm{~L} / \mathrm{min}$ ). 
ことができた。ヘッドに沿って上昇する気流を噴流で除去 したと考える。

陽炎ブローが光路中の温度分布に与える影響について、 解析結果を Fig. 12 に示す。陽炎ブローが無い場合、光路 中の空気はへッド側面 $\mathrm{X}_{\mathrm{h}}$ 近傍で最大 $65^{\circ} \mathrm{C}$ まで温度上昇し た。高温、低温のピークを複数個持つ不均一な分布となり、

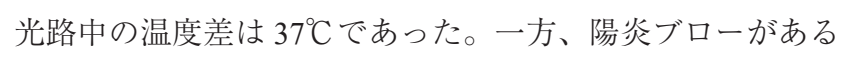
場合、カメラカバー外部の $\mathrm{X}_{\mathrm{h}}$ から $\mathrm{X}_{\mathrm{s}}$ までの位置では 28

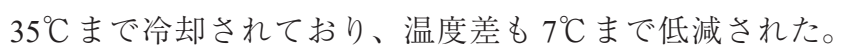
カメラカバー内部の境界面 $\mathrm{X}_{\mathrm{h}}$ からカバー $\mathrm{X}_{\mathrm{c}}$ までの間では $37^{\circ} \mathrm{C}$ となり、ほぼ一様の温度分布を示した。以上のように、 陽炎ブローにより、光路上の温度ばらつきは著しく低減さ れた。

なお、ヘッド側面 $X_{\mathrm{h}}$ における温度は、噴流がある場合、 噴流なしの場合よりも $3^{\circ} \mathrm{C}$ 低い。噴流により緩やかな速度 の風が当たったためと考える。

\subsubsection{PIV 法による流速分布の測定}

噴流による気流の影響の評価結果を Fig. 13 に示す。陽 炎ブローが無い場合、Fig. 13 (a) に示すように、複数個の 渦が緩やかに形を変えながら装置の手前から奥方向に向 かって流れる様子を観察した。最大流速は $0.3 \mathrm{~m} / \mathrm{s}$ であった。 平面方向に流れが生じた原因としては、レーザの切断面が ウエハに対し一定の傾きがあるため、上昇気流成分を捉え たことや、測定時の装置内の空気の流れが考えられる。

一方、噴流がある場合の流速分布を Fig. 13 (b) に示す。 噴流が当たった部分において、複数個の渦は消滅した。ノ ズルの噴射方向に最大流速 $2.5 \mathrm{~m} / \mathrm{s}$ の気流が流れた。噴流近 傍の気流は、噴流の影響を受け、噴流と同一方向に流れる 傾向が見られた。以上のように、噴流がある場合において も、本熱流体解析手法による結果は PIV 法と同様の傾向を 示すことを確認した。

\section{3 認識精度の影響}

噴流が認識精度に与える影響の評価結果を Table 2 に示 す。常温では、認識精度がさ $0.3 \mu \mathrm{m}$ だったが、加熱により

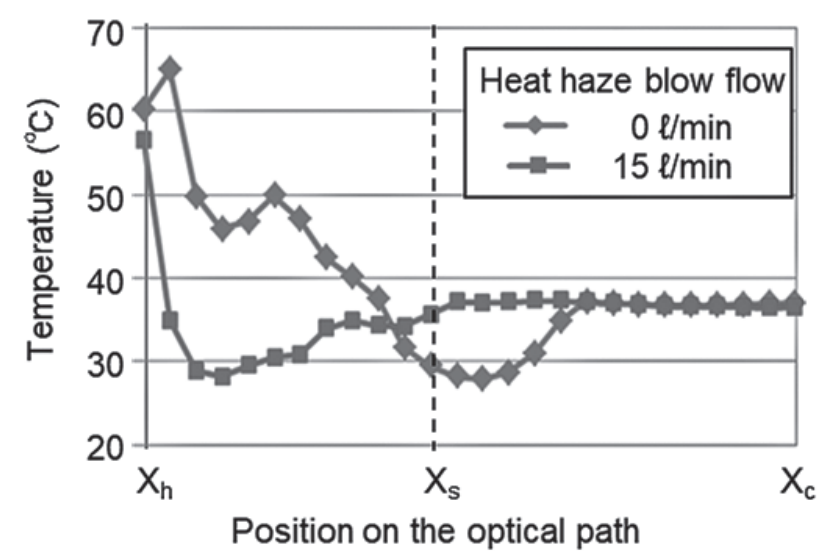

Fig. 12 Influence of the heat-haze blow flow on the flow temperature through the optical path.

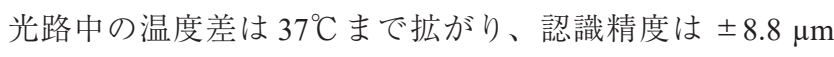
まで悪化した。一方、噴流により温度差は $10^{\circ} \mathrm{C}$ まで縮まり、 認識精度は土 $1.2 \mu \mathrm{m}$ まで改善した。

以上のことから、認識精度は光路中の空気の温度差と相 関があるとした熱流体解析の前提条件が妥当であったと言 える。

\section{5. 結 言}

チップオンウエハ実装工程において、加熱実装時の陽炎 により認識精度が悪化する問題に対し、加熱されたウエハ や加熱実装へッドによる自然対流や噴流によって変動する 空気の熱摇らぎ挙動を熱流体解析により定量化する方法を 検討した。

本研究の結果、得られた主な知見を以下に示す。

1） $150^{\circ} \mathrm{C}$ に加熱されたウエハの輻射熱により温められた気 流は、 $0.1 \mathrm{~m} / \mathrm{s}$ 程度の緩やかな速度で摇らぎながら上昇

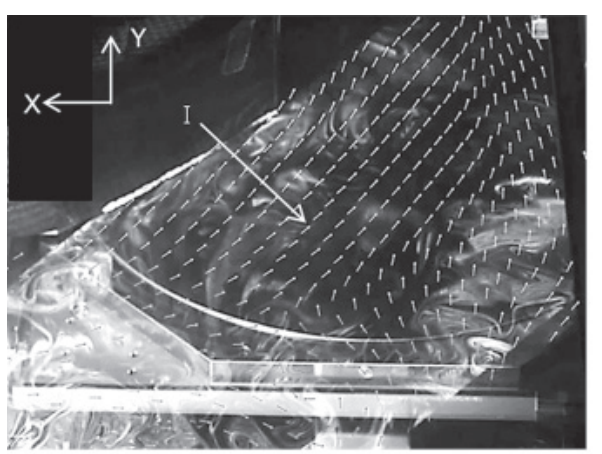

10mm

Velocity uv $(\mathrm{mm} / \mathrm{s})$

I $1-400$

II $400-800$

III $800-2526$

(a)

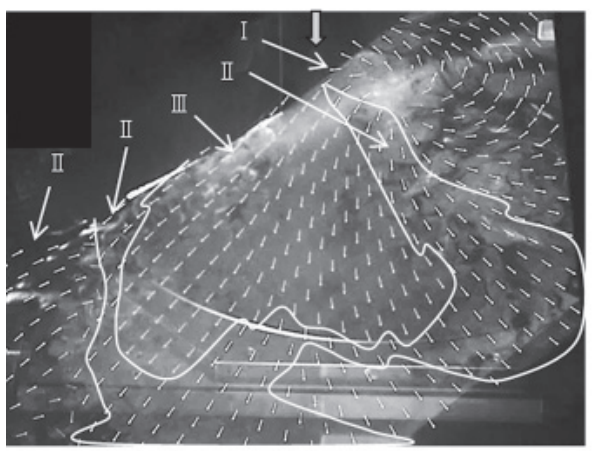

(b)

Fig. 13 Influence of heat-haze blow on the flow velocity by PIV (heat haze blow flow; (a) $0 \mathrm{~L} / \mathrm{min}$, (b) $15 \mathrm{~L} / \mathrm{min}$ ).

Table 2 Results of the recognition accuracy.

\begin{tabular}{|c|c|c|c|c|}
\hline \multicolumn{2}{|l|}{ No. } & Ref. & A & B \\
\hline \multicolumn{2}{|l|}{ Head temperature $\left({ }^{\circ} \mathrm{C}\right)$} & 25 & 200 & 200 \\
\hline \multicolumn{2}{|l|}{ Wafer temperature $\left({ }^{\circ} \mathrm{C}\right)$} & 30 & 150 & 150 \\
\hline \multicolumn{2}{|c|}{ Heat haze blow flow $\left({ }^{\circ} \mathrm{C}\right)$} & 0 & 0 & 15 \\
\hline \multicolumn{2}{|c|}{ Temperature difference $(\ell / \mathrm{min})$} & 0 & 58 & 10 \\
\hline \multirow{2}{*}{$\begin{array}{l}\text { Recognition accuracy } \\
(\mu \mathrm{m})\end{array}$} & $\mathrm{x}$ & \pm 0.3 & \pm 8.8 & \pm 1.1 \\
\hline & $\mathrm{y}$ & \pm 0.3 & \pm 5.4 & \pm 1.2 \\
\hline
\end{tabular}


する挙動を示すことが分かった。さらに、加熱ウエハ の上方に実装へッドを配置すると、ヘッドが常温であっ てもウエハからの上昇気流の流速がヘッド近傍部で増 幅され、その結果ヘッド近傍の空気の温度が上昇する ことが分かった。

2）光路中の熱摇らぎを除去するために、実装へッドとカ メラ間に流量 $15 \mathrm{~L} / \mathrm{min}$ の陽炎ブローを噴射すると、最 大流速 $5 \mathrm{~m} / \mathrm{s}$ の噴流が発生し、加熱ウエハによって生じ た複数個の渦流は噴流とともに光路外に排出されるこ とが分かった。さらに、陽炎ブローによって、検証モ デルにおける光路中の温度差を $37^{\circ} \mathrm{C}$ から $10^{\circ} \mathrm{C}$ まで低減 できることが分かった。

3）陽炎ブローにより温度差を $37^{\circ} \mathrm{C}$ から $10^{\circ} \mathrm{C}$ まで低減する と、加熱実装時の認識精度を $\pm 8.8 \mu \mathrm{m}$ から $\pm 1.2 \mu \mathrm{m}$ ま で向上できることが分かった。認識精度を向上するに は光路中の温度差を低減することが有効であることが 分かった。

\section{謝 辞}

本研究の遂行にあたり、パナソニック(株)在籍中に検証装 置に関する技術支援とアドバイスをいただきました向島仁 氏に感謝の意を表します。

\section{参考文献}

1）配線板製造技術委員会：“次世代エレクトロニクス機器対応の 実装技術の最新動向”、エレクトロニクス実装学会誌、20-1, (2017) 14-19.

2) M. Brunnbauer, T. Meyer, G. Ofner, K. Mueller, R. Hagen: Embedded Wafer Level Ball Grid Array (eWLB), 33rd IEEE/CPMT International Electronics Manufacturing Technology Conference (IEMT), (2008) 1-6.

3) Curtis Zwenger et al.: Electrical and Thermal Simulation of SWIFT тм High-density Fan-out PoP Technology, IEEE 67th Electronic Components and Technology Conference, (2017) 1962-
1967.

4) D. Hiner et al.: SLIM тм Advanced Fan-out Packaging for High Performance Multi-die Solutions, IEEE 67th Electronic Components and Technology Conference, (2017) 575-580.

5) N. Motohashi, T. Kimura, K. Mineo, Y. Yamada, T. Nishiyama, et al.: System in wafer-level package technology with RDL-first process, Electronic Components and Technology Conference (ECTC), 2011 IEEE 61st, (2011) 59-64.

6) C.F. Tseng, C.S. Liu, C.H Wu, and D.Yu: InFO (Wafer Level Integrated Fan-Out) Technology, 2016 IEEE 66th Electronic Components and Technology Conference, (2016) 1-6.

7) Douglas Yu: A New Integration Technology Platform: Integrated Fan-Out Wafer-Level-Packaging for Mobile Applications, 2015 Symposium on VLSI Technology Digest of Technical Papers, (2015) T46-47.

8) Jérôme Azémar; Fan-Out Wafer-Level-Packaging: Market and Technology Trends, International Symposium on Microelectronics: Fall 2016, 2016-1 (2016) 000176-000179.

9）石田博之：ウエハ仮接合・剥離技術の最新動向、FO-WLP の 開発動向 - プロセス・封止・仮接合・材料 - 、ジャパンマー ケティングサーベイ (2016) 15.

10）中尾修: 電子部品実装機の高速 ·高精度位置決め、精密工学 会誌、62-9 (1996) 1259-1262.

11）外村幸博：高速ダイボンダ技術、日本機械学会誌、08-1039 (2005) 482-483.

12) D. Sakurai, T. Osumi, K. Ushirokawa, T. Nakamura, T. Ishikawa: High Productive Micro Solder Flip Chip Bonding Process, Transactions of The Japan Institute of Electronics Packaging, 5 -1 (2012) 99-106.

13）星貴之、早田滋：画像計測高精度化のための超音波定在波に よる空気摇らぎの抑制、計測自動制御学会論文集 52-10 (2016) 518-523.

\section{代表者メールアドレス}

櫻井大輔ｓakurai.daisuke@jp.panasonic.com 